ISSN: 1858-4837; E-ISSN: 2598-019X

Volume 17, Nomor 1 (2022),

https://jurnal.uns.ac.id/region

DOI: 10.20961/region.v17i1.50919

\title{
Potensi dan permasalahan penyediaan air bersih di Kelurahan Kariangau menggunakan root cause tree analysis
}

\author{
Potential and problems analysis of clean water supply in Kariangau Village with \\ root cause tree analysis method
}

\author{
W A Dewantoro ${ }^{1}$ dan D T Sitaresmi ${ }^{1}$ \\ ${ }^{1}$ Program Studi Perencanaan Wilayah dan Kota, Jurusan Teknik Sipil dan Perencanaan, \\ Institut Teknologi Kalimantan
}

Corresponding author's email: wahyudewantoro89@gmail.com

\begin{abstract}
Abstrak. Kebutuhan akan air bersih menjadi salah satu hal yang sangat diperhatikan, terutama dalam pemenuhan kebutuhan air domestik maupun non domestik. Pada Kelurahan Kariangau meskipun telah terlayani oleh salah satu instalasi pengolahan air, menurut RPLP Kota Balikpapan tahun 2018 hanya sebesar 65\% masyarakat terlayani sarana air bersih untuk keperluan mandi dan cuci yang mengindikasikan permasalahan terkait dengan penyediaan air bersih pada Kelurahan Kariangau. Penelitian ini dilakukan untuk menganalisis potensi serta permasalahan yang berkaitan dengan penyediaan air bersih dan mengidentifikasi akar permasalahan dari penyediaan air bersih. Analisis yang digunakan pada penelitian ini yaitu root cause analysis dengan langkah pertama yaitu analisis skala likert untuk mengidentifikasi potensi dan permasalahan penyediaan air bersih, current reality tree untuk menentukan akar permasalahan serta diagram fault tree sebagai ilustrasi akar permasalahan. Berdasarkan hasil analisis didapatkan potensi dari penyediaan air bersih yaitu warna air, bau air, rasa, kandungan zat kimia, kandungan biologis, volume penampungan air masyarakat dan sumber air alternatif. Permasalahan yang diperoleh yaitu waktu menampung air, banyaknya jumlah air pada sumber, distribusi air dalam 24 jam, distribusi air per jam kegiatan, keterjangkauan jarak, keterjangkauan waktu. Akar permasalahan yang diperoleh yaitu debit air rendah, belum tersedia pipa distribusi air bersih, pengaruh musim, ketersediaan sumber air, penggunaan air secara komunal, serta lokasi sumber air.
\end{abstract}

Kata Kunci: Air Bersih; Akar Permasalahan; Penyediaan Air

Received: May 03, 2021; Accepted: October 22, 2021; Available online: January 31, 2022

Copyright $@$ 2022, REGION: Jurnal Pembangunan Wilayah dan Perencanaan Partisipatif 


\begin{abstract}
Need for clean water is one great concern, especially in meeting domestic and non-domestic water needs. In Kariangau Village even though it has been served by one of the Water Treatment Plants, according to the RPLP of Balikpapan City in 2018 , only $65 \%$ of the community is served with clean water facilities for bathing and washing purposes which indicates problems related to the provision of clean water in Kariangau Village. This research aims to analyse the potential and problems associated with the provision of clean water and to identify the root causes of water supply. The analysis used root cause analysis with the first step of likert scale analysis to identify the potential and problems of clean water supply, the current reality tree to determine the root of the problem, and the fault tree diagram to illustrate the root of the problem. The result obtained potential from the provision of clean water, namely water colour, smell, taste, chemical, biological, volume of community water storage, and alternative water sources. Meanwhile, the problems obtained are the time to collect water, the amount of water at the source, the distribution of water in 24 hours, the distribution of water per hour of activity, the affordability of the distance, and the affordability of time. The root of the problem obtained is low water discharge, no clean water distribution pipe, the influence of the season, the availability of water sources, communal use of water, and the location of water sources.
\end{abstract}

Keywords: Clean Water; Root Cause; Water Supply

\title{
1. Pendahuluan
}

Kebutuhan akan air bersih menjadi salah satu hal yang sangat diperhatikan terutama dalam pemenuhan kebutuhan air baik kebutuhan domestik maupun non domestik. Dimana air domestik berdasarkan dari World Health Organization (WHO) [1] merupakan air yang dipergunakan untuk konsumsi pribadi baik untuk diminum, kebutuhan mandi, dan persiapan makanan yang biasanya dikonsumsi oleh rumah tangga. Berdasarkan Peraturan Menteri Kesehatan Nomor 492/2010 tentang Kualitas Air Minum, air bersih yang dikonsumsi oleh masyarakat (air minum) adalah air yang telah melalui proses pengolahan atau tanpa proses pengolahan yang telah memenuhi syarat kesehatan sehingga air tersebut dapat langsung dikonsumsi [2]. Air menjadi faktor penting dalam kebutuhan masyarakat dikarenakan penggunaan yang penting dalam kehidupan sehari-hari [3]. Berdasarkan standar pelayanan air bersih Peraturan Menteri Pekerjaan Umum dan Perumahan Rakyat Nomor 27 Tahun 2016 tentang Penyelenggaraan Sistem Penyediaan Air Minum disebutkan bahwa minimal keterlayanan air bersih mewajibkan pencapaian akses sarana air bersih secara berkelanjutan minimal $80 \%$ (masyarakat indonesia) dan melihat kebutuhan minimal setiap orang akan air bersih perhari yaitu 60 liter atau 0,006 $\mathrm{m}^{3}$ [4]. Berdasarkan Utilitas Bangunan Modul Plumbing tahun 2015 [5], dalam usaha penyediaannya air bersih perlu memperhatikan tiga syarat penyediaannya seperti syarat fisik, syarat kimia, serta syarat bakteriologis. Penyediaan tingkat kabupaten/ kota berdasarkan dari standar pelayanan minimal (SPM) yang dilihat berdasarkan dari jumlah penduduk dikalikan dengan ketersediaan air baku di kota/kabupaten tersebut. Hal tersebut sesuai dengan standar pelayanan air minum dan sanitasi [6], dilihat dari seberapa besar persentase keterlayanan masyarakat oleh sarana air bersih. Kota balikpapan sebagai salah satu kota yang terdapat di Provinsi Kalimantan timur yang masuk dalam kategori kota 
layak huni dengan indeks sebesar $65,8 \%$ dan terkenal sebagai kota dengan industri pengolahan minyak, gas serta jasa sebagai penggerak utama perekonomiannya. Sebagai salah satu kota layak huni di Indonesia, Kota Balikpapan tidak terlepas dari permasalahan perkotaan. Salah satunya permasalahan terkait dengan distribusi air bersih yang mengalami permasalahan yaitu kurang maksimalnya distribusi air pada beberapa wilayah di kota tersebut. Kelurahan yang memiliki permasalahan dalam bidang air bersih yaitu Kelurahan Kariangau. Berdasarkan Peraturan Daerah Kota Balikpapan Nomor 10 Tahun 2014 Kelurahan kariangau dilayani oleh pipa transmisi jalur Waduk Wain dengan pelayanan IPA Kariangau dan mencakup kelurahan Karang Joang, Batu Ampar dan Kelurahan Kariangau [7]. IPA Waduk wain sendiri memiliki kapasitas produksi sebesar 350 liter/detik. Meskipun telah tersedia instalasi pengolahan air yang melayani kelurahan tersebut, hanya sebesar $65 \%$ masyarakat yang memiliki akses air minum untuk keperluan mandi dan cuci (perpipaan ataupun non perpipaan yang terlindung dengan layak) dengan hanya $51 \%$ masyarakat yang terpenuhi kebutuhan air bersihnya [8]. Permasalahan persentase pelayanan air bersih di kawasan tersebut akan mempengaruhi kualitas Kota Balikpapan sebagai salah satu komponen sosial budaya masyarakat yang mendukung Kota Layak Huni Balikpapan. Oleh karena itu, penelitian ini dilakukan untuk mengetahui potensi dan permasalahan penyediaan air bersih di Kelurahan Kariangau sehingga dapat terciptanya Balikpapan sebagai kota yang layak huni.

\section{Metode}

Dalam mengidentifikasi potensi dan permasalahan pada penyediaan air bersih di Kelurahan Kariangau dilakukan dengan: (a) Penentuan isu penyediaan air bersih di kelurahan yang digunakan yaitu berdasarkan kondisi eksisting dari pelayanan air bersih di Kelurahan Kariangau dimana pelayanan air bersih hanya sebesar $65 \%$ dari seluruh masyarakat yang terlayani. (b) Identifikasi undesired effect atau UDE dari sintesa pustaka, yaitu:

- Warna air

- Rasa air

- Bau air

- Zat kimia dalam air

- Hewan atau organisme dalam air

- Volume penampungan air

- Waktu yang diperlukan untuk menampung air

- Banyaknya jumlah air bersih pada sumber

- Adanya sumber air alternatif (selain PDAM)

- Distribusi air (24 jam)

- Distribusi air (jam kegiatan)

- Keterjangkauan jarak

- Keterjangkauan waktu

Undesired effect tersebut yang menjadi pertanyaan dasar terkait dengan penyediaan pelayanan air bersih di Kelurahan Kariangau. Identifikasi ini dijadikan sebagai dasar atau indikasi awal permasalahan yaitu adakah sesuatu yang memperburuk kualitas pelayanan air bersih di Kelurahan Kariangau serta apa dampak negatif yang dirasakan masyarakat dari 
penyediaan air bersih di Kelurahan Kariangau. Selain itu, identifikasi dari undesired effect dibantu dengan penilaian untuk mendukung identifikasi menggunakan skala likert dengan penilaian 1 sampai dengan 4. (c) Identifikasi penyebab rantai hubungan sebab akibat berdasarkan dari pemetaan undesired effect yang kemudian dibandingkan dengan kejelasan kondisinya, kondisi eksisting dari permasalahan, dan penyebab permasalahan. Kemudian, setelah didapatkan elemen tersebut maka dilanjutkan dengan mengetahui timbal balik serta keberadaan akibat dari permasalahan. (d) Penyusunan diagram alir (flowchart) yang dilakukan untuk mempermudah dalam pembuatan pohon realita (Current Reality Tree/CRT) seperti pada Gambar 1.

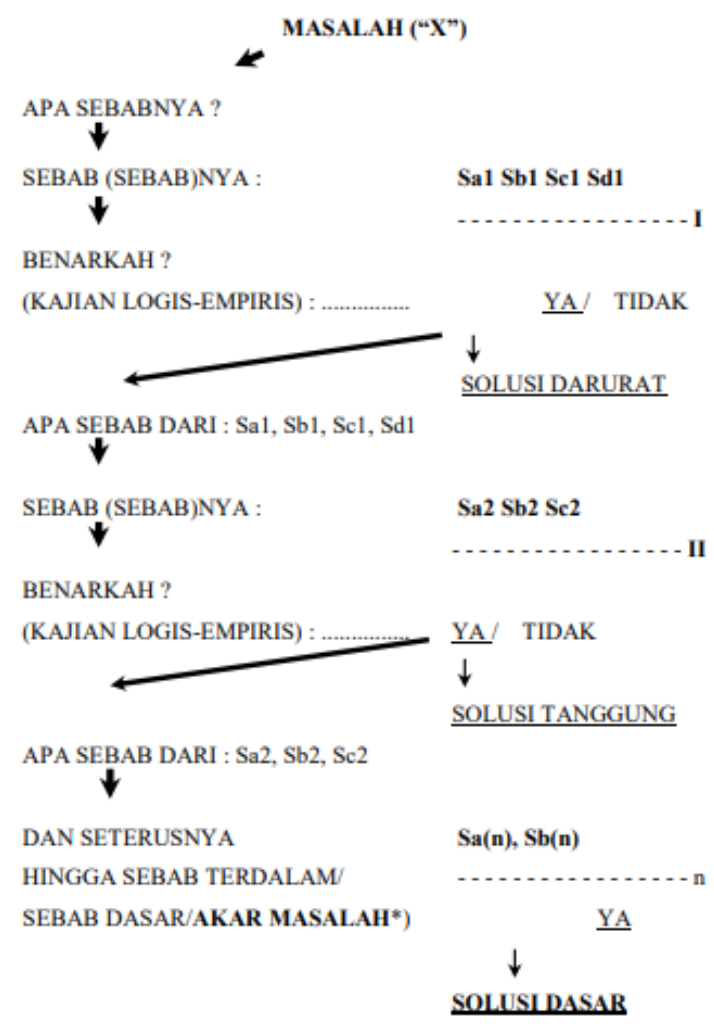

Gambar 1. Diagram alur permasalahan atau current reality tree.

Teknik pengambilan data yang digunakan yaitu dengan metode sekunder yang dilakukan dengan survei instansi pemerintah untuk memperoleh data pendukung penelitian. Selain itu, pengambilan data primer yang dilakukan dengan wawancara untuk memperoleh penilaian masyarakat terkait dengan identifikasi potensi dan permasalahan penyediaan air bersih. Dengan populasi dari pelaksanaan wawancara ini yaitu masyarakat pada kelurahan ini berdasarkan RT yang terdiri dari 12 RT yaitu RT 01, 02, 03, 04, 05, 06, 07, 08, 10, 11, 12, dan 13. Adapun berdasarkan profil Kelurahan Kariangau didapatkan jumlah penduduk sebesar 4.598 jiwa dengan masyarakat yang belum terlayani air bersih sebesar 1.609 jiwa yang tersebar pada 12 RT di Kelurahan Kariangau. Kriteria penentuan populasi yaitu masyarakat yang belum memiliki pelayanan air bersih, terdapat sebesar $30 \%$ dari penduduk di Kelurahan 
Kariangau. Menyesuaikan kriteria wawancara yaitu memungkinkan setiap individu dapat memberikan atau mengeluarkan pendapat serta cukup untuk memperoleh pendapat atau masukan penelitian. Untuk metode penarikan sampel yang diperlukan dalam penelitian ini yaitu masyarakat di Kelurahan Kariangau yang belum terlayani penyediaan air bersih sehingga diharapkan masyarakat tersebut mengetahui bagaimana pelayanan air bersih yang terdapat di Kelurahan Kariangau. Sampel yang dibutuhkan penelitian ini dapat menggunakan perhitungan dengan menggunakan metode slovin sebagai berikut:

$$
\mathrm{n}=\frac{N}{1+N e^{2}}
$$

Keterangan:

$$
\begin{array}{ll}
\mathrm{N} & =\text { Jumlah populasi } \\
\mathrm{n} & =\text { Jumlah sampel } \\
\mathrm{e} & =\text { Nilai error }
\end{array}
$$

Dengan menggunakan rumus di atas, dapat dilakukan perhitungan jumlah sampel yang dibutuhkan untuk penelitian ini. Dalam perhitungan sampel ini, ditetapkan nilai error penelitian ini adalah $5 \%$ atau 0,05 . Selanjutnya dilakukan perhitungan kebutuhan sampel dengan contoh seperti langkah perhitungan dibawah ini:

$$
\begin{aligned}
\mathrm{nRT}_{1} & =\frac{58}{1+58(0,05)^{2}} \\
\mathrm{nRT}_{1} & =\frac{58}{1+58(0,0025)} \\
\mathrm{nRT}_{1} & =\frac{58}{1+0,145} \\
\mathrm{nRT}_{1} & =50,65 \approx 51
\end{aligned}
$$

Berdasarkan contoh perhitungan pada RT 1 maka dapat diketahui bahwa sampel pada RT 1 yaitu sebanyak 51 responden. Adapun pembagian responden tersebut berdasarkan masingmasing RT krusial dengan tingkat ketersediaan air dibawah $80 \%$ yang terdiri dari RT $01,02,06$, 07, 08, dan 11. Maka didapatkan sampel pada masing-masing RT seperti pada Tabel 2.

Tabel 1. Sampel penelitian.

\begin{tabular}{ccc}
\hline RT & Populasi (KK) & Sampel Penelitian \\
\hline RT 01 & 58 & 51 \\
RT 02 & 49 & 44 \\
RT 06 & 49 & 44 \\
RT 07 & 7 & 7 \\
RT 08 & 63 & 54 \\
RT 11 & 50 & 44 \\
\multicolumn{2}{c}{ Jumlah } & 244 \\
\hline
\end{tabular}




\section{Hasil penelitian dan pembahasan}

Potensi dan permasalahan penyediaan air bersih pada wilayah penelitian didapatkan melalui hasil pengukuran variabel penelitian yang dijadikan sebagai dasar dalam menentukan urgensi potensi serta permasalahan dengan menggunakan metode RCA (Root Cause Analysis) untuk mengetahui akar permasalahan penyediaan air bersih di Kelurahan Kariangau. Analisis ini dapat dilakukan dengan melakukan penilaian berdasarkan masing-masing variabel dengan memberikan skor sehingga terdapat penilaian untuk menentukan prioritas maupun permasalahan utama pada masing-masing variabel. 13 variabel tersebut (lihat Tabel 2) memiliki penilaian berbeda berdasarkan masing-masing responden. Masing-masing skor tersebut memberikan definisi yang berbeda dimana penilaian skor 1 menandakan bahwa sebuah variabel sangat tidak baik, skor 2 menandakan sebuah variabel tidak baik, skor 3 menandakan variabel baik, skor 4 menandakan variabel sangat baik.

Tabel 2. Undesired effect.

\begin{tabular}{cl}
\hline Variabel & \multicolumn{1}{c}{ Keterangan } \\
\hline$V_{1}$ & Warna \\
$V_{2}$ & Rasa \\
$V_{3}$ & Bau \\
$V_{4}$ & Zat kimia \\
$V_{5}$ & Biologis \\
$V_{6}$ & Volume penampungan air \\
$V_{7}$ & Waktu yang diperlukan untuk menampung \\
$V_{8}$ & Banyaknya jumlah air pada sumber \\
$V_{9}$ & Adanya sumber air alternatif \\
$V_{10}$ & Distribusi air selama 24 jam \\
$V_{11}$ & Distribusi air per jam \\
$V_{12}$ & Keterjangkauan jarak \\
$V_{13}$ & Keterjangkauan waktu \\
\hline
\end{tabular}

Berdasarkan dari data diatas maka dapat dilakukan perhitungan untuk mengetahui skor maksimum dan minimum dari variabel diatas dengan asumsi bahwa nilai maksimum menandakan masyarakat memiliki tingkat penyediaan yang sangat baik, begitu juga sebaliknya. Jika semakin mendekati nilai minimum maka tingkat penyediaan air bersih yang terdapat di Kelurahan Kariangau sangat tidak baik. Indeks penilaian diperoleh dari persentase total skor terhadap skor maksimum. Kemudian, dapat diklasifikasikan ke dalam empat kategori seperti pada Tabel 3. Hasil perhitungan indeks penilaian tiap variabel dapat dilihat secara menyeluruh pada Tabel 4.

Tabel 3. Indeks penilaian.

\begin{tabular}{cccc}
\hline Klasifikasi & Nilai (\%) & Klasifikasi & Nilai (\%) \\
\hline Sangat Baik & $76-100$ & Buruk & $26-50$ \\
Baik & $51-75$ & Sangat Buruk & $0-25$ \\
\hline
\end{tabular}


Tabel 4. Indeks penilaian berdasarkan hasil wawancara terhadap variabel undesired effects.

\begin{tabular}{|c|c|c|c|c|c|c|}
\hline No & Variabel & $\begin{array}{c}\text { Skala } \\
\text { Penilaian }\end{array}$ & $\begin{array}{c}\text { Jumlah } \\
\text { Responden }\end{array}$ & Nilai & $\begin{array}{c}\text { Nilai } \\
\text { Maksimum }\end{array}$ & $\begin{array}{c}\text { Indeks } \\
\text { Penilaian }\end{array}$ \\
\hline \multirow[t]{5}{*}{1.} & $\mathrm{~V}_{1}$ & 1 & 20 & 20 & & \\
\hline & & 2 & 136 & 272 & & \\
\hline & & 3 & 85 & 255 & & \\
\hline & & 4 & 3 & 12 & & \\
\hline & & Total Skor $\mathbf{V}_{1}$ & & 599 & 976 & $61 \%$ \\
\hline \multirow[t]{5}{*}{2.} & $V_{2}$ & 1 & 6 & 6 & & \\
\hline & & 2 & 150 & 300 & & \\
\hline & & 3 & 37 & 111 & & \\
\hline & & 4 & 51 & 204 & & \\
\hline & & Total Skor $\mathbf{V}_{2}$ & & 621 & 976 & $64 \%$ \\
\hline \multirow[t]{5}{*}{3.} & $V_{3}$ & 1 & 4 & 4 & & \\
\hline & & 2 & 173 & 346 & & \\
\hline & & 3 & 67 & 201 & & \\
\hline & & 4 & 0 & 0 & & \\
\hline & & Total Skor $\mathbf{V}_{\mathbf{3}}$ & & 551 & 976 & $57 \%$ \\
\hline \multirow[t]{5}{*}{4.} & $\mathrm{~V}_{4}$ & 1 & 3 & 3 & & \\
\hline & & 2 & 3 & 6 & & \\
\hline & & 3 & 138 & 414 & & \\
\hline & & 4 & 100 & 400 & & \\
\hline & & Total Skor $\mathbf{V}_{4}$ & & 823 & 976 & $84 \%$ \\
\hline \multirow[t]{5}{*}{5.} & $V_{5}$ & 1 & 3 & 3 & & \\
\hline & & 2 & 0 & 0 & & \\
\hline & & 3 & 109 & 327 & & \\
\hline & & 4 & 132 & 528 & & \\
\hline & & Total Skor $\mathbf{V}_{5}$ & & 858 & 976 & $88 \%$ \\
\hline \multirow[t]{5}{*}{6.} & $V_{6}$ & 1 & 3 & 3 & & \\
\hline & & 2 & 114 & 228 & & \\
\hline & & 3 & 33 & 99 & & \\
\hline & & 4 & 94 & 376 & & \\
\hline & & Total Skor $\mathbf{V}_{6}$ & & 706 & 976 & $72 \%$ \\
\hline \multirow[t]{5}{*}{7.} & $V_{7}$ & 1 & 111 & 111 & & \\
\hline & & 2 & 94 & 188 & & \\
\hline & & 3 & 39 & 117 & & \\
\hline & & 4 & 0 & 0 & & \\
\hline & & Total Skor $\mathbf{V}_{7}$ & & 416 & 976 & $43 \%$ \\
\hline \multirow[t]{5}{*}{8.} & $\mathrm{~V}_{8}$ & 1 & 49 & 49 & & \\
\hline & & 2 & 164 & 328 & & \\
\hline & & 3 & 31 & 93 & & \\
\hline & & 4 & 0 & 0 & & \\
\hline & & Total Skor $\mathbf{V}_{8}$ & & 470 & 976 & $48 \%$ \\
\hline \multirow[t]{3}{*}{9.} & $V_{9}$ & 1 & 2 & 2 & & \\
\hline & & 2 & 140 & 280 & & \\
\hline & & 3 & 102 & 306 & & \\
\hline
\end{tabular}

Received: May 03, 2021; Accepted: October 22, 2021; Available online: January 31, 2022 


\begin{tabular}{|c|c|c|c|c|c|c|}
\hline No & Variabel & $\begin{array}{c}\text { Skala } \\
\text { Penilaian }\end{array}$ & $\begin{array}{c}\text { Jumlah } \\
\text { Responden }\end{array}$ & Nilai & $\begin{array}{c}\text { Nilai } \\
\text { Maksimum }\end{array}$ & $\begin{array}{c}\text { Indeks } \\
\text { Penilaian }\end{array}$ \\
\hline & & 4 & 0 & 0 & & \\
\hline & & Total Skor $\mathbf{V}_{\mathbf{g}}$ & & 588 & 976 & $60 \%$ \\
\hline \multirow[t]{5}{*}{10.} & $V_{10}$ & 1 & 188 & 188 & & \\
\hline & & 2 & 54 & 108 & & \\
\hline & & 3 & 2 & 6 & & \\
\hline & & 4 & 0 & 0 & & \\
\hline & & Total Skor $\mathbf{V}_{10}$ & & 302 & 976 & $31 \%$ \\
\hline \multirow[t]{5}{*}{11.} & $V_{11}$ & 1 & 239 & 239 & & \\
\hline & & 2 & 5 & 10 & & \\
\hline & & 3 & 0 & 0 & & \\
\hline & & 4 & 0 & 0 & & \\
\hline & & Total Skor $V_{11}$ & & 249 & 976 & $26 \%$ \\
\hline \multirow[t]{5}{*}{12.} & $V_{12}$ & 1 & 182 & 182 & & \\
\hline & & 2 & 62 & 124 & & \\
\hline & & 3 & 0 & 0 & & \\
\hline & & 4 & 0 & 0 & & \\
\hline & & Total Skor $\mathbf{V}_{12}$ & & 306 & 976 & $31 \%$ \\
\hline \multirow[t]{5}{*}{13.} & $V_{13}$ & 1 & 241 & 241 & & \\
\hline & & 2 & 03 & 6 & & \\
\hline & & 3 & 0 & 0 & & \\
\hline & & 4 & 0 & 0 & & \\
\hline & & Total Skor $\mathbf{V}_{14}$ & & 247 & 976 & $25 \%$ \\
\hline
\end{tabular}

Kemudian, dapat diperoleh isu penyediaan air bersih yaitu:

a. $V_{1}$ (warna air). Berdasarkan dari hasil penilaian yang didapatkan, variabel warna air pada wilayah penelitian memiliki nilai sebesar 599. Berdasarkan dari perhitungan indeks didapatkan bahwa variabel warna air masuk dalam indeks penilaian baik. Hal tersebut mengindikasikan bahwa warna air pada wilayah penelitian memiliki kondisi yang masuk dalam kategori baik sehingga belum termasuk dalam potensi maupun permasalahan utama pada penelitian.

b. $V_{2}$ (rasa). Pada variabel rasa, nilai kualitas penyediaan yang terdapat pada kondisi eksisting menunjukkan bahwa warna air memiliki skor sebesar 621 dan masuk dalam kategori indeks penilaian $64 \%$ dengan penilaian baik. Hal tersebut mengindikasikan bahwa pada variabel rasa pada air yang terdapat pada wilayah penelitian memiliki kualitas penyediaan yang baik.

c. $V_{3}$ (bau). Pada variabel bau air ditunjukkan bahwa skor penilaian yang didapatkan sebesar 551 . Berdasarkan total skor tersebut didapatkan indeks penilaian pada variabel bau masuk dalam kategori baik dengan indeks penilaian sebesar 57\%. Hal tersebut mengindikasikan bahwa bau air pada wilayah penelitian memiliki kondisi baik sehingga masih masuk dalam penilaian yang baik.

d. $V_{4}$ (zat kimia). Berdasarkan dari perhitungan skor didapatkan bahwa kondisi zat kimia yang terdapat pada air pada lingkup penelitian memiliki nilai sebesar 823 dengan indeks penilaian $84 \%$ sehingga masuk dalam kategori penilaian sangat baik. Hal tersebut mengindikasikan bahwa kondisi air pada variabel zat kimia memiliki kondisi yang sangat baik tanpa adanya pencemaran. Sehingga 
menjadi salah satu potensi dimana belum adanya pencemaran zat kimia yang terdapat pada sumber air di Kelurahan Kariangau.

e. $V_{5}$ (biologis). Berdasarkan dari perhitungan skor didapatkan bahwa kondisi zat kimia yang terdapat pada air pada lingkup penelitian memiliki nilai sebesar 858 dengan indeks penilaian sebesar $88 \%$ sehingga masuk ke dalam kategori penilaian sangat baik. Berdasarkan indeks tersebut dapat diketahui bahwa kondisi air pada variabel biologis memiliki kondisi yang sangat baik atau dapat dikatakan bahwa tidak terdapat organisme tertentu pada air yang digunakan.

f. $V_{6}$ (volume penampungan air). Pada variabel volume penampungan air ditunjukkan bahwa skor yang dimiliki variabel ini yaitu 706. Berdasarkan total skor tersebut, variabel volume penampungan air yang ada pada lingkup penelitian memiliki nilai indeks sebesar $72 \%$ sehingga masuk dalam kategori baik. Hal tersebut menunjukkan bahwa masyarakat pada lingkup penelitian memiliki volume penampungan air yang cukup untuk memenuhi kebutuhan air bersih.

g. $V_{7}$ (waktu yang diperlukan untuk menampung). Variabel ini memiliki nilai skor sebesar 416, dengan nilai indeks $43 \%$ mengindikasikan bahwa kondisi variabel ini masuk ke dalam kategori buruk sehingga memiliki potensi sebagai permasalahan. Hal tersebut dikarenakan belum semua masyarakat memiliki efisiensi waktu untuk menampung air bersih pada tempat penampungan yang dimiliki dikarenakan beberapa alasan seperti ketersediaan air serta suplai air harian yang belum memadai.

h. $V_{8}$ (banyaknya jumlah air pada sumber). Berdasarkan dari perhitungan skor, didapatkan bahwa variabel ini memiliki nilai 470 atau masuk kedalam kategori buruk dengan indeks penilaian $48 \%$. Hal tersebut mengindikasikan bahwa kondisi jumlah air pada sumber yang digunakan belum memiliki kondisi yang cukup memadai dikarenakan masih bergantung terhadap curah hujan serta kondisi sumber air yang memang masih terbatas.

i. $V_{9}$ (adanya sumber air alternatif). Dengan skor penilaian sebesar 588 maka dapat dikatakan bahwa variabel yang mengacu terhadap adanya sumber air alternatif yang baik pada wilayah penelitian dengan indeks sebesar $60 \%$. Hal tersebut mengindikasikan bahwa masih terdapat sumber alternatif lainnya yang terdapat di wilayah studi.

j. $V_{10}$ (distribusi air selama 24 jam). Berdasarkan dari nilai yang didapatkan, dapat diindikasikan bahwa pada wilayah studi memiliki distribusi air yang tidak konstan. Hal tersebut dilihat dari nilai yang cukup rendah yaitu sebesar 302 yang menunjukkan bahwa kondisi dari distribusi air per hari (24 jam) tidak konstan. Hal tersebut dikarenakan keterbatasan pada sumber air yang terdapat di lokasi studi sehingga menyebabkan suplai air bersih yang belum konstan.

k. $V_{11}$ (distribusi air per jam). Dilihat dari nilai yang didapatkan dari penelitian, ditunjukkan bahwa kondisi distribusi air per jam juga memiliki kendala yaitu belum adanya suplai air secara konstan yang ditunjukkan dengan nilai sebesar 249 dengan indeks nilai sebesar $26 \%$. Belum adanya distribusi konstan pada jam aktivitas menyebabkan kondisi distribusi air per jam yang masuk dalam kategori buruk.

I. $V_{12}$ (keterjangkauan jarak). Dalam hal keterjangkauan jarak, penyediaan air memiliki kondisi yang buruk. Berdasarkan dari penilaian didapatkan skor sebesar 306 atau memiliki 
penilaian sebesar $31 \%$, sehingga keterjangkauan jarak juga dapat menjadi salah satu permasalahan pada penyediaan air bersih.

$\mathrm{m} . \mathrm{V}_{13}$ (keterjangkauan waktu). Pada keterjangkauan waktu juga memiliki nilai yang sangat rendah yaitu 247. Hal tersebut mengindikasikan bahwa kondisi penyediaan air bersih pada variabel keterjangkauan waktu memiliki kualitas yang sangat buruk. Indeks penilaian menunjukkan angka $25 \%$ sehingga menjadi salah satu variabel yang sangat buruk menurut masyarakat.

Berdasarkan interpretasi dari indeks penilaian pada Tabel 4, dapat diketahui apakah variabel tersebut adalah suatu potensi atau permasalahan. Variabel yang menjadi permasalahan kemudian diidentifikasi lagi untuk mengetahui akar permasalahannya (lihat Tabel 5).

Tabel 5. Perumusan root cause analysis.

\begin{tabular}{|c|c|c|c|c|}
\hline Variabel & $\begin{array}{c}\text { Potensi/ } \\
\text { Permasalahan }\end{array}$ & $\begin{array}{c}\text { Kategori } \\
\text { Permasalahan }\end{array}$ & Akar Permasalahan & Sumber \\
\hline Warna & Potensi & Baik & - & $\begin{array}{l}\text { Survei primer, } \\
2020\end{array}$ \\
\hline Rasa & Potensi & Baik & - & $\begin{array}{l}\text { Survei primer, } \\
2020\end{array}$ \\
\hline Bau & Potensi & Baik & - & $\begin{array}{l}\text { Survei primer, } \\
2020\end{array}$ \\
\hline Zat Kimia & Potensi & Sangat baik & - & $\begin{array}{l}\text { Survei primer, } \\
2020\end{array}$ \\
\hline Biologis & Potensi & Sangat baik & - & $\begin{array}{l}\text { Survei primer, } \\
2020\end{array}$ \\
\hline $\begin{array}{l}\text { Volume } \\
\text { penampungan } \\
\text { air }\end{array}$ & Potensi & Baik & - & $\begin{array}{l}\text { Survei primer, } \\
2020\end{array}$ \\
\hline $\begin{array}{l}\text { Waktu yang } \\
\text { diperlukan } \\
\text { untuk } \\
\text { menampung }\end{array}$ & Permasalahan & Buruk & $\begin{array}{l}\text { Debit air rendah } \\
\text { Belum tersedia pipa } \\
\text { distribusi air bersih }\end{array}$ & $\begin{array}{l}\text { Survei primer, } \\
2020\end{array}$ \\
\hline \multirow[t]{2}{*}{$\begin{array}{l}\text { Banyaknya } \\
\text { jumlah air pada } \\
\text { sumber }\end{array}$} & Permasalahan & Buruk & $\begin{array}{l}\text { Pengaruh alami musim } \\
\text { Ketersediaan sumber air } \\
\text { (volume air pada } \\
\text { sumber yang digunakan } \\
\text { masyarakat) }\end{array}$ & $\begin{array}{l}\text { Survei primer, } \\
2020\end{array}$ \\
\hline & & & $\begin{array}{l}\text { Penggunaan komunal } \\
\text { sumber air }\end{array}$ & \\
\hline $\begin{array}{l}\text { Adanya sumber } \\
\text { air alternatif }\end{array}$ & Potensi & Baik & - & $\begin{array}{l}\text { Survei primer, } \\
2020\end{array}$ \\
\hline $\begin{array}{l}\text { Distribusi air } \\
\text { selama } 24 \text { jam }\end{array}$ & Permasalahan & Buruk & $\begin{array}{l}\text { Belum terdapat sistem } \\
\text { perpipaan }\end{array}$ & $\begin{array}{l}\text { Survei primer, } \\
2020\end{array}$ \\
\hline $\begin{array}{l}\text { Distribusi air } \\
\text { per jam }\end{array}$ & Permasalahan & Buruk & $\begin{array}{l}\text { Belum terdapat sistem } \\
\text { perpipaan }\end{array}$ & $\begin{array}{l}\text { Survei primer, } \\
2020\end{array}$ \\
\hline
\end{tabular}




\begin{tabular}{|c|c|c|c|c|}
\hline Variabel & $\begin{array}{c}\text { Potensi/ } \\
\text { Permasalahan }\end{array}$ & $\begin{array}{c}\text { Kategori } \\
\text { Permasalahan }\end{array}$ & Akar Permasalahan & Sumber \\
\hline $\begin{array}{l}\text { Keterjangkauan } \\
\text { jarak }\end{array}$ & Permasalahan & Buruk & $\begin{array}{l}\text { Lokasi sumber air } \\
\text { Belum terdapat sistem } \\
\text { perpipaan } \\
\text { Lokasi sumber air }\end{array}$ & $\begin{array}{l}\text { Survei primer, } \\
2020\end{array}$ \\
\hline $\begin{array}{l}\text { Keterjangkauan } \\
\text { waktu }\end{array}$ & Permasalahan & Sangat buruk & $\begin{array}{l}\text { Belum terdapat sistem } \\
\text { perpipaan } \\
\text { Lokasi sumber air }\end{array}$ & $\begin{array}{l}\text { Survei primer, } \\
2020\end{array}$ \\
\hline
\end{tabular}

Berdasarkan tabel diatas maka dapat diperoleh bahwa isu penyediaan air bersih di Kelurahan Kariangau yang masuk dalam kategori buruk yaitu waktu yang diperlukan untuk menampung air, banyaknya jumlah air pada sumber, distribusi air selama 24 jam dan per jam aktivitas, keterjangkauan jarak dan keterjangkauan waktu. Setelah diperoleh isu penyediaan air maka dapat dilanjutkan dengan pembentukan current reality tree berdasarkan flowchart yang menghasilkan variabel serta akar permasalahan (lihat Tabel 6).

Tabel 6. Hasil current reality tree.

\begin{tabular}{|c|c|c|}
\hline Variabel & Akar Permasalahan & Kajian Empiris \\
\hline $\begin{array}{lr}\text { Waktu } & \text { yang } \\
\text { diperlukan } & \text { untuk }\end{array}$ & & $\begin{array}{l}\text { Debit air mempengaruhi waktu yang } \\
\text { diperlukan masyarakat dikarenakan debit air }\end{array}$ \\
\hline menampung air & Debit air rendah & $\begin{array}{l}\text { mempengaruhi kecepatan aliran air pada } \\
\text { suatu penampang (sistem distribusi) air dan } \\
\text { mempengaruhi kualitas penyediaan air [9]. }\end{array}$ \\
\hline & $\begin{array}{l}\text { Belum adanya pipa distribusi } \\
\text { air }\end{array}$ & $\begin{array}{l}\text { Ketersediaan pipa distribusi menjadi sistem } \\
\text { utama dalam penyediaan sambungan rumah } \\
\text { dari pipa pembawa air dari bak penampung } \\
\text { (reservoir) sampai jaringan pelayanan [10]. }\end{array}$ \\
\hline \multirow[t]{2}{*}{$\begin{array}{l}\text { Banyaknya jumlah } \\
\text { air pada sumber }\end{array}$} & $\begin{array}{l}\text { Dipengaruhi oleh musim } \\
\text { (musim hujan memiliki } \\
\text { jumlah air lebih banyak } \\
\text { dibandingkan dengan musim } \\
\text { kemarau) }\end{array}$ & $\begin{array}{l}\text { Air pada musim hujan memiliki debit air yang } \\
\text { lebih besar dibandingkan dengan musim } \\
\text { kemarau, hal tersebut mempengaruhi } \\
\text { bagaimana jumlah air pada suatu sumber } \\
\text { dipengaruhi oleh musim (alami) [5]. }\end{array}$ \\
\hline & $\begin{array}{l}\text { Penggunaan air secara } \\
\text { komunal }\end{array}$ & $\begin{array}{l}\text { Penggunaan sumber air secara komunal } \\
\text { (lebih dari } 1 \mathrm{KK} \text { ) akan mempengaruhi kualitas } \\
\text { dan kuantitas air bersih [11]. }\end{array}$ \\
\hline
\end{tabular}

Distribusi air selama Belum terdapat sistem 24 jam perpipaan

Ketersediaan pipa distribusi menjadi sistem utama dalam penyediaan sambungan rumah dari pipa pembawa air dari bak penampung (reservoir) sampai jaringan pelayanan [10].

Distribusi air selama Belum terdapat sistem Ketersediaan pipa distribusi menjadi sistem jam aktivitas perpipaan utama dalam penyediaan sambungan rumah dari pipa pembawa air dari bak penampung (reservoir) sampai jaringan pelayanan [10].

Lokasi sumber air Lokasi sumber air menjadi salah satu faktor utama dalam memberikan kemudahan 


\begin{tabular}{|c|c|c|}
\hline Variabel & Akar Permasalahan & Kajian Empiris \\
\hline & & $\begin{array}{l}\text { aksesibilitas masyarakat untuk memperoleh } \\
\text { air [1]. }\end{array}$ \\
\hline \multirow[t]{2}{*}{$\begin{array}{l}\text { Keterjangkauan } \\
\text { jarak }\end{array}$} & $\begin{array}{l}\text { Belum terdapat } \\
\text { perpipaan }\end{array}$ & $\begin{array}{l}\text { Ketersediaan pipa distribusi menjadi sistem } \\
\text { utama dalam penyediaan sambungan rumah } \\
\text { dari pipa pembawa air dari bak penampung } \\
\text { (reservoir) sampai jaringan pelayanan [10]. }\end{array}$ \\
\hline & Lokasi sumber air & $\begin{array}{l}\text { Lokasi sumber air menjadi salah satu faktor } \\
\text { utama dalam memberikan kemudahan } \\
\text { aksesibilitas masyarakat untuk memperoleh } \\
\text { air [1]. }\end{array}$ \\
\hline \multirow[t]{2}{*}{$\begin{array}{l}\text { Keterjangkauan } \\
\text { waktu }\end{array}$} & $\begin{array}{l}\text { Belum terdapat } \\
\text { perpipaan }\end{array}$ & $\begin{array}{l}\text { Ketersediaan pipa distribusi menjadi sistem } \\
\text { utama dalam penyediaan sambungan rumah } \\
\text { dari pipa pembawa air dari bak penampung } \\
\text { (reservoir) sampai jaringan pelayanan [10]. }\end{array}$ \\
\hline & Lokasi sumber air & $\begin{array}{l}\text { Lokasi sumber air menjadi salah satu faktor } \\
\text { utama dalam memberikan kemudahan } \\
\text { aksesibilitas masyarakat untuk memperoleh } \\
\text { air [1]. }\end{array}$ \\
\hline
\end{tabular}

Berdasarkan hasil perumusan dari current reality tree pada tabel diatas, maka dapat dilanjutkan dalam mengilustrasikan diagram fault tree analysis. Diagram ini diilustrasikan untuk memudahkan pemahaman terkait dengan akar permasalahan dari penelitian yang dilakukan. Gambar 2 merupakan ilustrasi dari diagram fault tree analysis dari akar permasalahan penyediaan air bersih di Kelurahan Kariangau. 


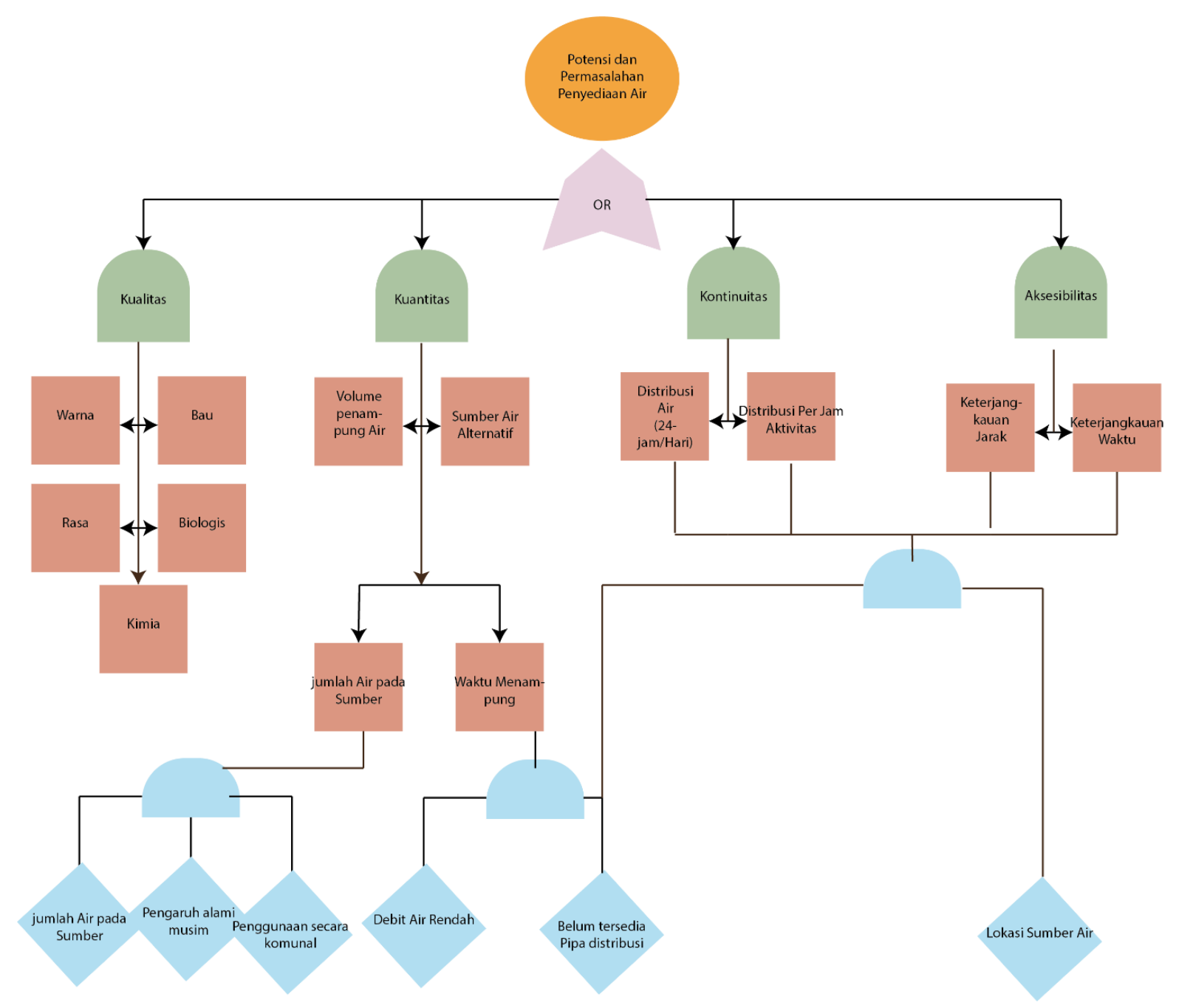

Gambar 2. Diagram fault tree analysis.

\section{Kesimpulan}

Berdasarkan dari 4 variabel dan 13 sub variabel yang diperoleh berdasarkan sintesa pustaka didapatkan potensi dan permasalahan dari penyediaan air bersih di Kelurahan Kariangau. Potensi tersebut antara lain: warna air, rasa air, bau, zat kimia, biologis, volume penampungan air masyarakat, dan sumber air alternatif. Sedangkan untuk permasalahan yaitu: waktu untuk menampung air, banyaknya jumlah air pada sumber, distribusi air selama 24 jam, distribusi air per jam aktivitas, keterjangkauan jarak, dan keterjangkauan waktu. Dengan akar permasalahan yang diperoleh yaitu debit air rendah, belum tersedia pipa distribusi air bersih, pengaruh musim terhadap ketersediaan air, penggunaan sumber air secara komunal, ketersediaan sumber air, serta lokasi sumber air. Hasil dari penelitian ini juga dapat dijadikan sebagai bahan pertimbangan dalam memperhatikan bagaimana tingkat penyediaan air bersih dan untuk mengetahui perumusan permasalahan pada penyediaan air bersih pada lokasi lain yang memiliki permasalahan yang identik. 


\section{Referensi}

[1] World Health Organization. Guidelines for Drinking-Water Quality Third Edition World Health Organization. 3rd ed. Geneva: WHO Press; 2008.

[2] Peraturan Menteri Kesehatan Republik Indonesia Nomor 492/Menkes/Per/IV/2010 Tentang Persyaratan Kualitas Air Minum.

[3] Kodoatie RJ, Syarief R. Pengelolaan Sumber Daya Air Terpadu. Yogyakarta: Penerbit Andi; 2007.

[4] Peraturan Menteri Pekerjaan Umum dan Perumahan Rakyat Nomor 27/PRT/M/2016 Tentang Penyelenggaraan Sistem Penyediaan Air Minum.

[5] Pusat Pendidikan dan Pelatihan Sumber Daya Air dan Konstruksi. Hidrologi, Ketersediaan dan Kebutuhan Air. Bandung: Kementerian Pekerjaan umum Dan Perumahan Rakyat; 2017.

[6] Peraturan Menteri Pekerjaan Umum Nomor 01/PRT/M/2014 tentang Standar Pelayanan Minimal Bidang Pekerjaan Umum dan Penataan Ruang.

[7] Peraturan Daerah Kota Balikpapan Nomor 10 Tahun 2014 Tentang Perubahan Atas Peraturan Daerah Nomor 3 Tahun 2008 Tentang Perusahaan Daerah Air Minum Kota Balikpapan.

[8] Dinas PUPR Kota Balikpapan. Rencana Penataan Lingkungan Permukiman Kelurahan Kariangau kota Balikpapan Tahun 2017-2018. 2017.

[9] Todd DK. Ground Water Hydrology. New York: John Wiley and Sons; 1959.

[10] Direktorat Jenderal Cipta Karya. Buku 4 Panduan Pendampingan Sistem Penyediaan Air Minum (SPAM) Perpipaan Berbasis Masyarakat. Jakarta: Kementerian Pekerjaan umum Dan Perumahan Rakyat; 2016.

[11] Sastavyana S. Penentuan Model Sistem Penyediaan Air Minum Perdesaan yang Berkelanjutan di Kabupaten Subang. J Wil Dan Perenc Kota 2010;21:81-94. 